Archives de sciences sociales des religions

112 | octobre-décembre 2000

Âme et corps : conceptions de la personne

\title{
MONTCLOS (Christine de), Le Vatican et l'éclatement de la Yougoslavie
}

Paris, 1999, PU.F., 262 p. (bibliogr.)

\section{Enzo Pace}

\section{OpenEdition}

\section{Journals}

Édition électronique

URL : http://journals.openedition.org/assr/20445

DOI : $10.4000 /$ assr. 20445

ISSN : $1777-5825$

\section{Éditeur}

Éditions de l'EHESS

Édition imprimée

Date de publication : 31 décembre 2000

Pagination : 162

ISBN : 2-222-96698-1

ISSN : 0335-5985

\section{Référence électronique}

Enzo Pace, "MONTCLOS (Christine de), Le Vatican et l'éclatement de la Yougoslavie », Archives de sciences sociales des religions [En ligne], 112 | octobre-décembre 2000, document 112.91, mis en ligne le 19 août 2009, consulté le 21 septembre 2020. URL : http://journals.openedition.org/assr/20445 ;

DOI : https://doi.org/10.4000/assr.20445

Ce document a été généré automatiquement le 21 septembre 2020

(c) Archives de sciences sociales des religions 


\section{MONTCLOS (Christine de), Le Vatican et l'éclatement de la Yougoslavie}

Paris, 1999, PU.F., 262 p. (bibliogr.)

\section{Enzo Pace}

\section{RÉFÉRENCE}

MONTCLOS (Christine de), Le Vatican et l'éclatement de la Yougoslavie, Paris, 1999, PU.F., 262 p. (bibliogr.)

1 L'auteur, juriste de formation, a consacré depuis longtemps ses travaux au rôle de l'Église catholique dans les relations internationales, en particulier sous le pontificat de Jean Paul II. Elle se donne ici courageusement comme objectif la reconstruction des choix de l'Église romaine face à la complexité de la crise balkanique : du soutien de la demande d'indépendance des Croates et des Slovènes à l'appel fait aux puissances mondiales de recourir à l'intervention humanitaire dans la crise bosniaque ainsi qu'au Kosovo.

2 La thèse centrale de l'A. s'exprime à travers le concept d'ingérence active du Vatican durant toute la crise des Balkans. Le Saint-Siège s'est ainsi exposé à d'inévitables contradictions : d'un côté il a pu soutenir le droit à la sécession de la Slovénie et de la Croatie, de l'autre il a fini par accueillir le principe international du respect des frontières existantes dans le cas du Kosovo.

3 Ce ne fut donc pas une tâche aisée pour l'Église que de tracer une nette frontière entre la doctrine classique (pour le catholicisme) de la guerre juste et le moderne droit à l'ingérence humanitaire au sein des États nationaux et son cortège inévitable de légitimité du recours à la force en cas de nécessité. 